\title{
WhO IS AfRaid OF THE BIg BAD Social CONSTRUCTIONISTS? OR SHEDdING LIGHT ON THE UNPARDONABLE WHITENESS OF THE Canadian Legal Profession
}

\author{
CHARLES C. SMITH ${ }^{*}$
}

This article considers the lack of racial diversity in the legal profession, which is lower than other comparable professions. The author focuses on accessibility to the legal profession and entry into the practice. Historically, access was limited, and sometimes prohibited, by discriminatory social and statutory barriers. Tuition for post-secondary education is now a central barrier that increasingly divides along racial lines, due to the nexus between class and race. Despite the attention given to the problem of lack of racial diversity in the legal field through reports, task forces, surveys, and so forth, there is still much progress needed in order to ensure that the diversity of the profession reflects the makeup of the country's population. The author advocates the elimination of barriers to legal education and subsequent entry into the profession through cooperative initiatives between schools, firms, legal associations, and community organizations in order to increase racial equity and diversity within Canada's legal profession.
Cet article porte sur le manque de diversité raciale dans la profession juridique, c'est-à-dire qu'elle est inférieure à celle des professions comparables. $L$ 'auteur se concentre sur l'accessibilité et la pratique de la profession juridique. Traditionnellement, l'accès était limité et parfois interdit en raison d'obstacles sociaux et statutaires discriminatoires. Les frais de scolarité de l'enseignement postsecondaire représentent denos jours un obstacle central qui divise de plus en plus les races en raison de la connexion qui existe entre classe sociale et race. Malgré l'attention que les rapports, les groupes de travail, les sondages et autres accordent au manque de diversité raciale dans le domaine juridique, beaucoup de progrès est nécessaire pour que la profession reflète la diversité de la population du pays. L'auteur préconise l'élimination des obstacles à l'éducation juridique et ensuite l'entrée dans la profession au moyen d'initiatives coopératives entre les écoles, les firmes, les associations juridiques et les organismes communautaires en vue d'améliorer l'équité et la diversité raciale au sein de la profession juridique au Canada.

\section{TABLE OF CONTENTS}

I. INTRODUCTION .............................. 55

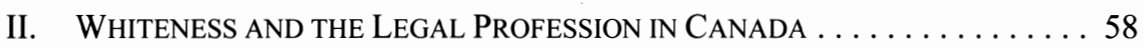

III. CONTEMPORARY CHALLENGES AND THE UNPARDONABLE

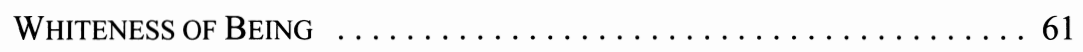

IV. What CAN Be Done AND By Whom $\ldots \ldots \ldots \ldots \ldots \ldots \ldots \ldots \ldots \ldots \ldots$

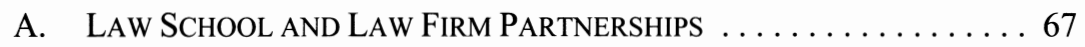

B. Regulators and Legal Associations $\ldots \ldots \ldots \ldots \ldots \ldots \ldots$

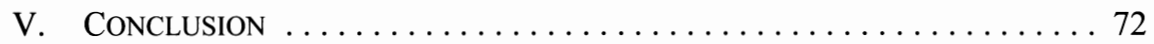

\section{INTRODUCTION}

In 2005, I was asked to participate in a session entitled, "The Implications of 'BleachedOut' Professionalism for Racialized Lawyers and Communities," which was one of the

Lecturer, University of Toronto at Scarborough; Research Associate, Canadian Centre for Policy Alternatives; former Equity Advisor, Canadian Centre for Policy Alternatives; former Equity Advisor, Law Society of Upper Canada. I have taken some liberty with the title based on Derrick A. Bell, "Who's Afraid of Critical Race Theory?" (1995) U. Ill. L. Rev. 893. 
former Chief Justice of Ontario's forums to discuss contemporary issues within the legal profession. ${ }^{1}$ At the time, I remarked that the title of this forum is one of those metaphors that seems easy to grasp. Most of us are aware of efforts within the legal profession, including law schools, law firms, the courts, and so forth, to diversify their representation so that it is more inclusive of the racialized and cultural makeup of the broader society. The record of positive intention has been and continues to be articulated repeatedly in studies, reports, policies and programs that are written, developed, and implemented by law schools, law societies, legal associations, and law firms. Since the 1993 report of the Task Force on Gender Equality in the Legal Profession, chaired by Bertha Wilson J. (as she then was), ${ }^{2}$ a considerable number of these reports and studies have been published. ${ }^{3}$

Over the past eight years I have had the benefit of working in three legal associations on these issues. I have also provided advice and services to several law firms and legal associations. Through all of this, I have gained considerable insight into the challenges related to this topic. This experience has enabled me to research this matter and to develop policies and programs for the Law Society of Upper Canada (LSUC), the Canadian Bar Association (CBA) and, very recently, the Indigenous Bar Association(IBA) where I support their efforts to form a national secretariat to identify, challenge, and eliminate hate and racism in Canada. ${ }^{4}$

It is for these reasons that I questioned the topic of this session. There are two notions which are at issue here. One is that "Bleached-Out Professionalism" suggests eradicating stains or foreign elements in order to return to or "create" a more homogenous, uniform construction. And this is exactly where the second contentious issue emerges. I shall phrase

1 This article was first delivered at the Chief Justice of Ontario's Advisory Committee on Professionalism, Fourth Colloquium on the Legal Profession, "Accessing the Justice in Professionalism," University of Windsor, 3 March 2005.

2 Canadian Bar Association (CBA), Task Force on Gender Equality in the Legal Profession, Touchstones for Change: Equality, Diversity and Accountability - The Report on Gender Equality in the Legal Profession (Ottawa: Canadian Bar Association, 1993).

3 See e.g. Rajeev Dhavan, Neil Kibble \& William Twining, eds., Access to Legal Education and the Legal Profession (London: Butterworths, 1989); Felix N. Weekes \& A. Elliot Spears, Survey of Black Law Students, Black Articling Students, and Recently Called Black Lawyers, July - August 1992 (Toronto: Law Society of Upper Canada, 1992); Patricia Monture-Angus, Thunder in my Soul: A Mohawk Woman Speaks (Halifax: Fernwood, 1995) at 90-128; Law Society of Upper Canada (LSUC), Bicentennial Report and Recommendations on Equity Issues in the Legal Profession (Toronto: Law Society of Upper Canada, 1997); Canadian Bar Association, Working Group on Racial Equality in the Legal Profession, Racial Equality in the Legal Profession (Ottawa: Canadian Bar Association, 1999) [CBA, Racial Equality]; Law Society of Upper Canada, Concerns Regarding Discrimination in Attracting Articling Positions (Toronto: Law Society of Upper Canada, 2000); Law Society of Upper Canada, Articling Student Feedback Report (Toronto: Law Society of Upper Canada, 2001); Law Society of British Columbia (LSBC), Equity and Diversity Committee, Aboriginal Law Graduates Working Group, Addressing Discriminatory Barriers Facing Aboriginal Law Students and Lawyers (Vancouver: Law Society of British Columbia, 2000); Canadian Bar Association, Ten Years Into the Future: Where Are We Now After Touchstones? (Ottawa: Canadian Bar Association, 2003); F.M. Kay, C. Masuch \& P. Curry, Diversity and Change: The Contemporary Legal Profession in Ontario, A Report to the Law Society of Upper Canada (Toronto: Law Society of Upper Canada, 2004).

4 One of the issues this group has been concerned about is the appointment of Aboriginal judges to higher courts, including the Supreme Court of Canada. See National Secretariat Against Hate and Racism Canada, Position on Aboriginal Appointments to the Supreme Court of Canada and Provincial Courts, Including Courts of Appeal, online: Indigenous Bar Association (IBA) $<\mathrm{http}$ ://www.indigenousbar ca/pdf/aborjudges.pdf $>$. 
it in the form of a question: Assuming that "bleaching" renders its objects white, when was the legal profession not bleached? ${ }^{5}$ Was there ever really a need to "bleach" it? Or would it not be more important to talk about "unbleaching" the profession, particularly now given the challenges faced by Aboriginal peoples and subordinate racialized groups who enter it?

Looking at the faulty metaphor conjures up the great difficulty the legal profession has in talking about race and racism in society generally, and within its ranks in particular. Rather than talk about race and racism directly, problematic metaphors are used. Given the rather undramatic increase in the numbers of Aboriginal lawyers and lawyers from subordinate racialized groups, one would think this issue would be named directly. However, it appears that there is a lack of commitment by the legal profession to produce concrete results aimed at ensuring that the profession reflects the makeup of the Canadian population. For example, a recent article entitled "Reducing the Democratic Deficit: Representation, Diversity and the Canadian Judiciary, or Towards a "Triple P' Judiciary," points out the challenges in increasing the racial diversity of the bench. One of the key challenges the authors encountered in doing their research was that there was no information at the federal level about the racialized composition of the bench and that the same finding held true for most provinces and territories. ${ }^{7}$ Further, neither law societies nor the CBA have canvassed their members to assess their representation based on race or Aboriginal status.

On a related point, Alan J.C. King, Wendy K. Warren, and Sharon R. Miklas note in their recent study of "accessibility" in five Ontario law schools that "[a]dmissions policies that target groups with unique characteristics are not necessarily intended to produce a student body that mirrors the Canadian population." 8 As well, the former Governor General of Canada recently commented on the difficulties in increasing the racial diversity of the legal profession, ${ }^{9}$ and the Law Society of British Columbia (LSBC) produced a report on discriminatory barriers faced by Aboriginal law students and lawyers. ${ }^{10}$

In this regard, the legal profession, which may pride itself on being "different" because of its adherence to the rule of law and democratic principle, is really not unlike other professions or the Canadian society at large. Or as Troy Duster wrote in his submission to the Association of American Law Schools (AALS):

Oddly enough, the concept of "bleaching" has two opposing definitions depending on usage, i.e. popular usage in terms of bleaching clothing to make it white, or photographic bleaching which actually supports colouring of photographs.

6 Richard Devlin, A. Wayne MacKay \& Natasha Kim, "Reducing the Democratic Deficit: Representation, Diversity and the Canadian Judiciary, or Towards a 'Triple P' Judiciary" (2000) 38 Alta. L. Rev. 734.

$7 \quad$ On this point, the authors state: "At the federal level, the only information provided was a list of the names of active and supernumery judges.... At the provincial and territorial levels, there was a disparate response" (ibid. at 760).

$8 \quad$ Alan J.C. King, Wendy K. Warren \& Sharon R. Miklas, Study of Accessibility to Ontario Law Schools (October 2004), online: Council of Canadian Law Deans <http://www.ccld-cdfdc.ca/Studyof Accessibility-Report.pdf $>$ at 81 .

9 See "Her Excellency the Right Honourable Adrienne Clarkson Speech on the Occasion of an Honorary Doctorate of Laws Degree from The Law Society of Upper Canada" (27 February 2003), online: Governor General of Canada <http://www.gg.ca/media/doc.asp?lang=e\&DOCID=1091>. 
Professions and the institutions which serve them tend to view themselves as having unique traditions, values, skills and missions - even callings. While to some degree this is true, from the perspective of students of higher education, there are strong patterns or parallel trends and forces for a wide range of academic disciplines and professional schools. These parallel experiences and subsequent institutional and organizational dilemmas are particularly salient when we look to the changes that are occurring and have occurred over the last twenty years in institutions of higher education around the shifting demographic composition of undergraduate and graduate student bodies. The experiences of other institutions - both educational and corporate - as they have confronted contested terrain around issues of gender, race, and ethnicity, can help clarify the strategies for addressing these areas of conflict or contest within schools of law. ${ }^{11}$

Evidence indicates the same dilemmas across the legal profession. Finally, one other underlying but critical issue is that the construction of a "bleached" or overwhelmingly white profession requires us to consider the agents behind the bleaching/whiteness. In other words, who is "bleaching" the legal profession? Or keeping it white? Why? How is this being done? And what must be done to change this?

The above discussion is the reason for the title and focus of this article. Given the number of studies, reports, policies, task forces, programs, and so forth, one might expect that the legal profession would be much further along in addressing issues of its racialized composition. One might expect more significant numbers of Aboriginal peoples and individuals from subordinate racialized groups to be studying and practising law, or results that were at least similar to other elite professions, such as medicine, engineering, and the professoriate. Unfortunately, this is not the case. The legal profession, for all its attention to issues of race, lags well behind these other professional fields and so, once again, we are gathered to discuss this fact.

My contention with this subject forms the basis of this article, and in discussing the legal profession, I also contend that it is essential to look at the pathways to it, which requires some discussion on the importance of education and, in particular, legal education.

\section{Whiteness and the Legal Profession in Canada}

Discursive analysis on the education of non-dominant groups and its influence on professional attainment has been emerging over the course of a considerable period of time, particularly that concerning legal education and entry into the practice of law. These matters do not exist in isolation, but rather form part of a social context in which relations between dominant and non-dominant groups are situated, especially in terms of race. This issue has been explored by Aboriginal thinkers and critical race theorists. ${ }^{12}$ Many of these authors

11 Troy Duster, "What We Can Learn From Other Experiences in Higher Education" in Perspectives on Diversity: AALS Special Commission on Meeting the Challenges of Diversity in An Academic Democracy (1997), online: Association of American Law Schools <http://www.aals.org/diversity/ duster.html> at c. 4 .

12 See e.g. Richard Delgado \& Jean Stefancic, Critical Race Theory: The Cutting Edge, 2d ed. (Philadelphia: Temple University Press, 2000); Kimberlé Crenshaw et al., Critical Race Theory: The Key Writings that Formed the Movement (New York: New Press, 1995); Adrien Katherine Wing, ed., Critical Race Feminism: A Reader, 2 d ed. (New York: New York University Press, 2003); Katharine 
contend that this relationship is symbiotic and based on an inequitable sharing of resources and power. In particular, Aboriginal peoples and peoples from subordinate racialized groups describe the power imbalance dominating their lives as a centrifugal force placing the pressures of assimilation squarely before them or blocking their access into society's elite professions. Further, as Cornel West notes, these prevailing forces, which are particularly influenced by the regime of law and legal education, have shaped and continue to shape social policy, institutional practices, and community interactions. ${ }^{13}$

In this context, discrimination in education and professional occupations is mirrored and reinforced by discrimination in society through statutes, social policy, institutional practices, or individual and community actions. Such statutes and practices are condoned as acceptable within the social mores of their times and, as such, impact on the abilities of non-dominant groups to participate in and benefit from the study and practice of law. In examining the whiteness of the legal profession, it is essential to look at the pathways to the practice of law. This means looking at access to a legal education and to those institutions which enable individuals to consider and pursue a legal education and legal practice. In this context, the history of racial discrimination in Canadian educational systems is inescapable.

For example, based on statutes adopted in 1850, such as The Common Schools Act ${ }^{14}$ in Ontario, separate schools for black children "continued until 1891 in Chatham, 1893 in Sandwich, 1907 in Harrow, 1917 in Amherstburg, and 1965 in North Colchester and Essex counties." ${ }^{15}$ Based on statutes dating back to 1833, black children were barred from attending the only public school in Halifax County until 1940, and in 1959, school buses still only stopped in white sections of Hammonds Plains. ${ }^{16}$ In 1960, there were seven formal black school districts and three additional exclusively black schools in Nova Scotia. ${ }^{17}$ The repeal of the Ontario and Nova Scotia statutes authorizing racial segregation in education did not occur until the mid-1960s. Further, the Indian Act $^{18}$ had extremely restrictive provisions regarding the education of Aboriginal peoples.

In terms of legal education, $\mathrm{W}$. Wesley Pue summarizes the racist values that contributed to the establishment of common law legal education in Canada. In detailing the history of its development, he writes:

The period from roughly 1910 to 1920 was important in laying new cultural foundations for modern common law legal education. It produced a melding of persuasive new ideas developed and tested in the USA with

T. Bartlett \& Rosanne Kennedy, Feminist Legal Theory: Readings in Law and Gender (Boulder, Colo.: Westview Press, 1991).

13 Cornel West, Keeping Faith: Philosophy and Race in America (New York: Routledge, 1993) at 195205, 207-25. See also Duncan Kennedy, "Legal Education and the Reproduction of Hierarchy" (1982) 32 J. Legal Educ. 591; Margaret Thornton, "Technocentrism in the Law School: Why The Gender and Colour of Law Remain the Same" (1998) 36 Osgoode Hall L.J. 369. (U.K.), 1850, 13 \& 14 Vict., c. 48.

15 Constance Backhouse, Colour-Coded: A Legal History of Racism in Canada (Toronto: University of Toronto Press, 1999) at 250 [citations omitted]. See also Ken Alexander \& Avis Glaze, Towards Freedom: The African-Canadian Experience (Toronto: Umbrella Press, 1996) at 235. Backhouse, ibid. at 251 [citations omitted].

Ibid.

R.S.C. 1985 , c. I-5. 
longstanding British middle class traditions regarding practical knowledge, honour and authority. For a variety of reasons English Canada's dominant cultural ethos was receptive to influences of both sorts. The conjuncture of industrialisation and westward expansion dominated English Canadian imperial visions.... Challenged by a world of ideas which held no traditions sacrosanct, English élites ... were freed and forced to reconsider their own futures. This reappraisal included fundamental questions about which sorts of institutional arrangements were best suited to the peculiar position of this new, northern, British, and free people. $^{19}$

In this context, Pue describes efforts by the Law Society of Manitoba to stop the development of proprietary schools which:

\footnotetext{
"Judging by U.S.A experience ... would also almost certainly have opened the door to legal careers for much larger numbers of young men (and women?) of working class or minority ethnic background. This prospect would not have been viewed with equanimity by Manitoba's Anglo élite, who were embedded in a culture which was fiercely pro-British and hierarchical, nativist, even xenophobic. ${ }^{20}$
}

Pue also notes "the most vigourous proponents of what might be called a 'cultural' agenda in legal education were prominent, energetic, busy, successful practising lawyers. All were either born into the Anglo élite or thoroughly integrated into it. All were active in matters of law society governance or in the activities of bar associations,"21 and further, that "the cultural assumptions of individuals in that period must be assessed if we are to make any sense of the history of common law legal education in Canada. If we are to understand at all, we have to begin to understand the intellectual climate of the élite, British, Protestant world in which these men lived." 22

Mirroring Pue's comments, Christopher Moore provides a sense of what the legal profession looked like in the nineteenth and early twentieth centuries. He notes that "[t]he vast majority of nineteenth century Ontario lawyers were English, Scots, or Irish in origin and Protestant in religion, and they tended to take in students of their own class and kind.... Throughout the nineteenth century, successful families from outside the Anglo-Protestant mainstream were occasionally able to find articling positions for sons inclined to the law."23

It was not until 1855 that Robert Sutherland was called to the Bar in Ontario, becoming the first black Canadian lawyer. ${ }^{24}$ This was followed by Delos Rogest Davis in $1885 .{ }^{25}$ Davis's call to the Bar was not a simple passage but, rather, required a special act of the

W. Wesley Pue, "Common Law Legal Education in Canada's Age of Light, Soap and Water" (1995) 23 Man. L.J. 654 at 661-62.

Ibid. at 669 [footnotes omitted].

Ibid. at 675 [footnotes omitted].

Ibid.

Christopher Moore, The Law Society of Upper Canada and Ontario's Lawyers: 1797-1997 (Toronto: University of Toronto Press, 1997) at 176.

Ibid. at 177. See also Ian Malcolm, "Robert Sutherland: The First Black Lawyer in Canada?" (1992) 26

Law Society Gazette 183.

See Lance C. Talbot, "History of Blacks in the Law Society of Upper Canada" (1990) 24 Law Society Gazette 65 at 65 . 
Ontario Legislature against which the LSUC protested. ${ }^{26}$ While information on other black students called to the practice of law is difficult to ascertain, it appears certain that the effects of discrimination in education, combined with racism in society generally, limited the number of black students who entered law school and, further, those who did enter faced barriers in undertaking legal education, particularly in attracting articling positions. ${ }^{27}$

Chinese, Japanese, South Asian, and Aboriginal peoples were prohibited from becoming members of the LSBC until 1947, and until 1948 for people of Japanese descent. ${ }^{28}$ Further, until it was amended in 1951, the Indian Act required Aboriginal peoples to relinquish their status if they were to pursue higher education. ${ }^{29}$ This prevented many Aboriginal peoples from entering university and considering a legal education.

The prevailing presence of social and statutory barriers made it barely possible, and in some cases impossible, for particular groups to receive a legal education in Canada and to enter into legal practice. These barriers have resulted in some communities having few successes in legal education and are a matter of grave concern in terms of efforts to promote equity and diversity in legal education and the legal profession.

\section{CONTEMPorary ChallengeS AND THE UNPARDONABLE WHITENESS OF BEING}

Michael Ornstein has conducted two studies of the demographic makeup of the legal profession. ${ }^{30}$ While focusing particularly on Ontario, his research provides insights into the personal characteristics of lawyers across Canada. In both of these studies, Ornstein confirms that the legal profession is predominantly white. ${ }^{31}$ This view is also supported by reports by the CBA and the LSBC. ${ }^{32}$ Ornstein points out that individuals from subordinate racialized groups and Aboriginal peoples tend to choose professions other than law for their careers. In some cases, the differences are quite significant. For example, in 2001, 3.1 percent of

26 Moore, supra note 23 at 177-79; Talbot, ibid. at 65. Davis was denied the opportunity to article. As such, he twice requested legislative action to enable him to be first a solicitor and then a barrister. See also Julius Isaac, “Delos Rogest Davis, K.C.” (1990) 24 Law Society Gazette 293.

See Historical Connexions, "Historical Connexions, Law Society of Upper Canada \& Black Lawyers" (1999) [unpublished, archived with author] 1-2. Delos Rogest Davis was one of several black Canadians called to the Bar who either did not have articling or found difficulties finding an articling position. See CBA, Racial Equality, supra note 3 at 3.

See ibid.

Michael Ornstein, Lawyers in Ontario: Evidence from the 1996 Census, A Report to the Law Society of Upper Canada (January 2001), online: LSUC <http://rc.lsuc.on.ca/pdf/equity/lawyers InOntario1 996.pdf $>$ [Ornstein, Lawyers in Ontario]; Michael Ornstein, The Changing Face of the Legal Profession, 1971-2001, A Report to the Law Society of Upper Canada (October 2004), online: LSUC $<$ http://www.lsuc.on.ca/media/convoct04_ornstein.pdf $>$ [Ornstein, Changing Face].

31 Ornstein, Lawyers in Ontario, ibid. at 6, 11, notes that the legal profession across Canada is 94.2 percent white and within Ontario is 92.7 percent white. Elizabeth Chambliss, "Organizational Determinants of Law Firm Integration” (1997) 46 Am. U.L. Rev. 669; David B. Wilkins \& G. Mitu Gulati, "Why are There so Few Black Lawyers in Corporate Law Firms? An Institutional Analysis" (1996) 84 Cal. L. Rev. 493. Further, in Stacey Mobley, Priming the Pipeline to Diversity in the Legal Profession (2001), online: Association of Corporate Counsel <http://www.acc.com/resource/v910 $>$ at 3 . The American Crown Counsel Association identified that people of colour comprise 8 percent of all lawyers and judges in the United States. 
Ontario lawyers were South Asian compared with 9.6 percent of physicians, 7.0 percent of engineers, 4.2 percent of university professors; and 2.1 percent of Ontario lawyers were Chinese compared with 7.7 percent of physicians, 9.6 percent of engineers, and 4.7 percent of university professors. ${ }^{33}$ While there is no data examining career choices within these communities, these results are a clear indication of the strong differences in this matter. Ornstein further notes that subordinate racialized groups comprise 25.9 percent of physicians, 27.3 percent of engineers, 15.2 percent of professors, 11.2 percent of high-level managers, and 15.7 percent of middle managers compared to 9.2 percent of lawyers. ${ }^{34}$

The racialized composition of the legal profession has been an issue for some time. Both statistical and anecdotal accounts have been written on this subject and, to date, numerous legal associations have been formed within subordinate racialized communities and amongst Aboriginal lawyers to provide opportunities for them to come together, nurture each other, and support each other's social, cultural, educational, and professional growth and development. $^{35}$

The legal profession is not alone in this dilemma. The experience of Aboriginal lawyers and those from subordinate racialized groups is not much different than that of individuals from these communities working within other professions. For example, in a recent submission to the United Nations International Committee on the Elimination of All Forms of Racial Discrimination, the African Canadian Legal Clinic summarized a number of common issues besetting peoples of African descent and other subordinate racialized groups in terms of equality in employment. ${ }^{36}$ This submission describes the numerous reports identifying challenges and barriers to equal employment and provides sociological data identifying the wage and position differential between groups based on race. In presenting this data, the report suggests that such differences are evident even when individuals from subordinate racialized groups have higher educational credentials than their white counterparts. $^{37}$

When it comes to the practice of law, while there may be nuances that are different from other professional fields, clear and compelling explorations demonstrating the commonality of this issue with those of other employment sectors have been addressed in a number of

See Ornstein, Changing Face, supra note 30 at 13.

Ibid.

There are a number of such associations within the community of practising lawyers. These include the Canadian Association of Black Lawyers, the Association of Chinese Lawyers, the South Asian Lawyers' Association, the IBA, and Rotiio' taties (an Ontario-based Aboriginal lawyers' group). There are also similar associations of students within law schools across Canada. These groups have been formed because of the experiences of prejudice, harassment, and discrimination its members have experienced from the dominant group within the legal profession. These experiences have led individuals within these associations to feel a sense of alienation from the "mainstream" of Canadian legal practice. As such, in addition to creating their own law firms, they have also created their own associations. Government's Compliance with the International Convention on the Elimination of All Forms of Racial Discrimination" (2002) [unpublished, archived at the African Canadian Legal Clinic]. 
articles. ${ }^{38}$ Further, law societies, the CBA, law schools, and law firms have undertaken various initiatives to address this challenge. ${ }^{39}$ Unfortunately, the pace of change appears to be very slow and this is particularly a concern in terms of the racial composition of Canada's largest and most prestigious law firms. For example, Michael St. Patrick Baxter suggests, "[h]ere is the reality. Based on the 1997 Canadian Law List, there are about 23 Bay Street firms in Toronto. These 23 firms represent a total of about 3,117 lawyers. Of these 3,117 Bay Street lawyers, about 20 are black. This represents six-tenths of 1 percent of the Toronto Bay Street lawyers." ${ }^{40}$ This has happened for several reasons: (1) because of the absence of a critical mass of Aboriginal lawyers or lawyers from subordinate racialized groups being within these law firms; (2) large law firms work in ways that are both alien and alienating to individuals from these communities; and (3) the impact of the discriminatory treatment, individual and systemic, that numerous individuals say they have experienced when working in these firms. ${ }^{41}$

As has been noted elsewhere, law schools are "the gatekeepers of legal education.... Ultimately the ethos of the profession is determined by the selection process at law school. In order to ensure that our legal system continues to fulfill its important role in Canadian society it is important that the best candidates be chosen." 42 This concern has been quite a focal point in terms of studying the issue of access to legal education and the implications of the deregulation of tuition fees on Aboriginal peoples and individuals from subordinate racialized communities, particularly in terms of the increasing costs of legal education and the potential barriers this may present to these communities. For example, two Ontario law schools approved significant increases to their tuition fees, marking a rise from approximately CDN\$2,451 in 1995 to $\$ 16,000$ for 2003-04 at the University of Toronto, and from \$3,228 in 1997 to approximately \$8,961 in 2003 at Queen's University. ${ }^{43}$ Further, the University of Toronto intends to increase tuition fees until they total \$22,000, and Queen's University has projected to increase its fees to $\$ 12,856$ by $2005 .^{44}$

Concerns regarding the impact of tuition fees on individuals from historically subordinate communities have been addressed by a number of organizations. For example:

38 See Michael St. Patrick Baxter, "Black Bay Street Lawyers and Other Oxymora" (1998) 30 Can. Bus. L.J. 267 at 270 [footnotes omitted] [Baxter, "Oxymora"]; Michael St. Patrick Baxter, "Black Bay Street Lawyers: Looking Back, Looking Ahead” (1994) 28 Law Society Gazette 32.

Several law societies and law schools have set up equity and diversity programs and committees to address this matter, and a number of corporate law firms have also established similar committees.

Baxter, "Oxymora," supra note 38 at 270 [footnotes omitted].

See e.g. African Canadian Legal Clinic, Summary of Concerns Regarding Proposed Law School Tuition Increases / Community Impact In An Already Exclusionary System (31 March 2003) [unpublished, archived at the African Canadian Legal Clinic].

Ibid. at 2, referring to Larry Chartrand et al., "Law Students, Law Schools, and their Graduates" (2001) 20 Windsor Y.B. Access Just. 211 at 212-13, citing Dickson J. (as he then was).

43 See Charles C. Smith, "Deregulation and accessibility for law students at the University of Toronto" in Denise Doherty-Delorme \& Erika Shaker, eds., Missing Pieces V: An Alternative Guide to Canadian Post-Secondary Education (Ottawa: Canadian Centre for Policy Alternatives, 2004) 75, online: Canadian Centre for Policy Alternatives <http://www.policyalternatives.ca/documents/National_ Office_Pubs/missing_pieces5.pdf $>$ at 75 .

Ibid. 
- Statistics Canada data indicates that 38.7 percent of youth aged 18-21 years from wealthy families attended university compared to 18.8 percent of youth from poorer families.

- In the report by the Canadian Centre for Policy Alternatives entitled Missing Pieces $V$ : An Alternative Guide to Canadian Post-Secondary Education, it is suggested that higher tuition fees result in lower participation rates and that "[r]esearchers at the University of Guelph found that $40 \%$ fewer students from low-income families were attending University after tuition fees rose." 45

- The Canadian Association of University Teachers suggests that, if current trends continue, access to post-secondary education will be increasingly divided along income lines.

- Recent census data indicates that Aboriginal peoples and individuals from subordinate racialized groups tend to fall below the Low-Income Cut Off (LICO) more so than others. The result of this is lowered earnings, leaving these groups less able to support the educational advancement of their children. ${ }^{46}$

The potential impact of increasing law school tuition fees has been explored by the University of Toronto. ${ }^{47}$ As the basis for increasing its law school tuition fees to CDN\$22,000, the University initiated a study to demonstrate that there would be little, if any, negative impact. This study was completed by the University's Provost and released to its Committee on Academic Policy and Programs of the Governing Council. The points noted immediately above are critical to examining the University of Toronto Provost's study on accessibility. However, the Provost's study "ignores the well-known history of disparate outcomes in legal practice, including articling, for specific groups and appears to operate on the assumption that once in law school all are equal. This masks deeply entrenched societal and systemic inequalities and evades a critical point on the likely deleterious impact that increasing tuition fees will have." 48

In terms of first-year students from families with low incomes, the report indicates that in 2002-2003, 17.3 percent of students came from families in the low-income area of less than $\$ 60,000$, compared to 33 percent of students with family incomes above $\$ 90,000$, and 33.5 percent of students who did not report their family income. ${ }^{49}$ Given that individuals from this latter group do not seek financial assistance, it is likely safe to assume that these individuals are financially well off. As such, this indicates that over 66 percent of students in the Faculty

$45 \quad$ Ibid. at 77.

$46 \quad$ Ibid. at $76-77$.

47 See Shirley Neuman, Provost's Study of Accessibility and Career Choice in the Faculty of Law (24 February 2003), online: University of Toronto <http://www.utoronto.ca/ gsunion/fees/accessibility study2003.pdf $>$.

48 Canadian Bar Association, Response to the Provost Study of Accessibility and Career Choice in the University of Toronto Faculty of Law (April 2003), online: CBA <http://www.cba/org/CBA/pdf/ SubmissionProvost_apr3.pdf $>$ at 5 [CBA, Response to Provost Study]. 
of Law came from families with incomes above $\$ 90,000$ per year as compared to 17 percent with incomes less than $\$ 60,000$ per year. ${ }^{50}$

This data supports the concerns expressed earlier, specifically that 38.7 percent of youth aged 18-21 from wealthy families attend university, compared to 18.8 percent of youth from poorer families and, further, that if such trends in increasing tuition fees continue, postsecondary education will be increasingly divided along class lines. Given the intersections between race and family incomes, these divisions will likely be along the lines of race as well.

Following this study, all five law schools in Ontario have examined the issue of accessibility in legal education and the implications/impact of deregulation of tuition fees. There are some startling indicators from this research, including that:

- $\quad$ Aboriginal students comprise 1.3 percent of law school students but make up 3.6 percent of the Ontario population and their numbers have decreased in law school; ${ }^{51}$

- The number of students of African descent have decreased in law school; ${ }^{52}$

- African-Canadian students are nearly twice as likely as their cohorts to leave law school with an accumulated debt of over CDN\$70,000 and South Asian students have significant numbers with similar debt loads $;^{53}$

- Choosing a specialization in law affects student course selection and most students prefer civil litigation and commercial law, which are the more financially lucrative areas of practice. This tendency has particular relevance to student interest in human rights and social justice studies, which has declined from 11 percent to 5.6 percent from first- to third-year students, with only 1.2 percent of recent graduates practising in these areas. ${ }^{54}$

Some of the comments of these students are worth noting. For example:

With the rising tuition costs, it will be very difficult for other black students like myself to have access to a legal education or to finish the legal education they have already commenced. I am one of five black law students in a class of 180 and I see the numbers going down in the future years because of the high expense incurred to go to law school and the few avenues available which provide financial assistance. (Year 3, Female) $)^{55}$

Ibid.

King, Warren \& Miklas, supra note 8 at 98.

Ibid. at 91.

Ibid. at 141 .

Ibid. at 32 .

Ibid. at 77 . 
If tuition costs keep going up, First Nations people will not be able to pursue professional careers. As it is now, most Bands will not allow its members to apply to $\mathrm{U}$ of $\mathrm{T}$ due to high cost. Raising costs will inhibit First Nations People's career choices. (Year 1, Female) ${ }^{56}$

Beyond the direct impact of increasing tuition fees, it is useful to once again review Ornstein's data on the significant earning differential between lawyers based on race. His research indicates that:

- White lawyers between the ages of 25-29 earn approximately CDN\$4,000 more per year than lawyers from subordinate racialized groups $(\$ 52,000$ versus $\$ 48,000)$. This gap increases to approximately $\$ 14,000$ for lawyers between the ages of 35-39 $(\$ 85,000$ versus $\$ 71,000)$, and to $\$ 39,000$ for lawyers between the ages of $40-44$ $(\$ 97,000$ versus $\$ 58,000) ;^{57}$

- Wage differentials between white lawyers and those from subordinate racialized communities are quite dramatic in the peak earning years of 50-54, with whites earning $\$ 70,000$ more. $^{58}$

As the CBA article on the University of Toronto study suggests:

\begin{abstract}
It is essential to highlight these points.... It is rather unusual to approach a study on accessibility and to decontextualize the fundamental issues affecting students, particularly their personal characteristics and how individuals from specific social groups have succeeded in the practice of law. By omitting reference to this information, the Provost study ignores the well-known history of disparate outcomes in legal practice, including articling, for specific groups and appears to operate on the assumption that once in law school all are equal. This masks deeply entrenched societal and systemic inequalities and evades a critical point on the likely deleterious impact that increasing tuition fees will have. ${ }^{59}$
\end{abstract}

The same might be said of King, Warren, and Miklas's study. Reviewing the earlier comments regarding students who graduate with higher debt loads and limited practice opportunities (Aboriginal peoples, South Asian, and African-Canadians), it is likely that increasing tuition fees will pose significant barriers to their entry and success in the practice of law.

\title{
IV. WHAT CAN BE DONE ANd BY WHOM
}

In specifically addressing access to the practice of law, Aboriginal lawyers and law students, as well as those from subordinate racialized groups, have stressed that the organizations within the legal profession need to demonstrate concrete results in terms of attracting, supporting, retaining, and promoting lawyers from their communities.$^{60}$ Over the years, it has been pointed out that large, prestigious law firms are not very racially diverse, that a number of articling students and lawyers from Aboriginal communities and subordinate

60 African Canadian Legal Clinic, Canadian Bar Association, Law Society of British Columbia. 
racialized groups have not had good experiences working in these firms and, as such, have left them. ${ }^{61}$

\section{A. LAW SCHOOL AND LAW Firm PARTNERSHIPS}

To address these concerns, it is useful to look at some of the promising practices in the United States. These practices signify the importance of law firms and law schools working together through specifically targeted initiatives aimed at increasing the racial diversity of legal education and practice. For example:

- Haynes and Boone LLP has established the Haynes \& Boone Minority Scholars Program which is available to first-year students at SMU Dedman School of Law and the University of Texas School of Law. For these efforts, the firm was given the prestigious Thomas L. Sager Award from the Minority Corporate Counsel Association for its commitment to improving the hiring, retention, and promotion of "minorities" and women in $2002 .^{62}$

- The Bar Association of San Francisco has established both a Bay Area Minority Summer Clerkship Program and Bay Area Minority Law Student Scholarship Program, in which the Association works with three bay area county bars to sponsor the First Year Minority Clerkship program. This program now involves 15-20 employers in the San Francisco area. Through this program, the Bar Association works with the following law schools: Boalt Hall School of Law, University of California; School of Law, University of California at Davis; Golden Gate University School of Law; Hastings College of Law, University of California; McGeorge School of Law, University of the Pacific; Santa Clara University School of Law; Stanford Law School; and School of Law, University of San Francisco. ${ }^{63}$

- Despite the impact of Hopwood v. Texas, ${ }^{64}$ the University of Texas Law School has established a number of programs to attract "minorities" to the study of law. For example, it set up the University of Texas Law School Partnership Task Force, which prepares undergraduate students at public colleges to compete as law school candidates and then succeed in law school. The Law School was declared by Time Magazine to be a national leader among schools working to broaden the traditional applicant pool. ${ }^{65}$ It was also named as the top law school for Latino students in 2002 by the Hispanic Business Magazine. ${ }^{66}$

This issue has also been written about by Baxter, "Oxymora," supra note 38 at 273: "the problem is attributable in large part to the fact that the people who, historically, have controlied the portals of the Bay Street firms have suffered from a lack of personal experience with blacks." index.aspx $>$. Law affirmative action program aimed at increasing the recruitment of African Americans and other under-represented groups. 
- The Sponsors for Educational Opportunity have established an internship program in the field of corporate law. This program allows interns opportunities to work with established lawyers on assignments that range from major corporate transactions to pro bono projects. Some of the law firms involved in this project include: Cleary Gottlieb Steen \& Hamilton LLP; Davis Polk \& Wardell LLP; Fried, Frank, Harris, Shriver \& Jacobson LLP; Milbank, Tweed, Hadley \& McCloy LLP; Shearman \& Sterling LLP; Simpson, Thacher \& Bartlett LLP; Sullivan \& Cromwell LLP; and Weil, Gotshal \& Manges LLP. ${ }^{67}$

- The Law School Admissions Council has established a program entitled PLUS (Pre-law Undergraduate Scholars Program), which provides grants to law schools to institute pre-law education programs to inspire students of colour to become lawyers and to provide them with knowledge, skills, and other forms of assistance that will strengthen their preparation for law school. ${ }^{68}$

- The Santa Clara University School of Law has set up a Summer High School Minority Law Program and established both the Russel W. Galloway Jr. Scholarship Fund, in memory of a law professor who was committed to diversity, and the Thurgood Marshall Scholarship Fund, named after the first AfricanAmerican appointed to the U.S. Supreme Court. In 2001, the University received the Law School Racial and Ethnic Diversity Award from the California Minority Counsel Program and was recognized as one of the ten most diverse law schools in the country by U.S. News \& World Report. ${ }^{69}$

- The American Association of Corporate Counsel has established a program entitled "Pipeline to Diversity in the Legal Profession." This program seeks to enable law firms to improve their recruitment and retention of minority candidates and has established a Review Board to guide its efforts as well as mentorship, outreach, and educational programs ${ }^{70}$ The Association participates with several groups, including the Minority Legal Education Resources Program, the Nashville High School Summer Intern Program, the Holland \& Knight Charitable Foundation Opening Doors Program in Palm Beach, and Streetlaw, Inc., which sponsors projects that law school students teach in high schools for academic credit.

See "Internship - Corporate Law," online: Sponsors for Educational Opportunity <http://www.seony.org/career/default.asp?page_id=96>. See Memorandum No. 02-100 PLUS Program Call for Proposals (29 October 2002) [unpublished]. See Press Release, "Law School wins award for commitment to ethnic and racial diversity" (12 June 2001), online: Santa Clara University <http://www.scu.edu/news/releases/release.cfm?month $=0601 \&$ story $=$ diversity $>$.

70 See Association of Corporate Counsel, "Priming the Pipeline to Diversity" (2001), online: Association of Corporate Counsel <http://www.acca.com/diversity/pipeline>. The Review Board for this program includes law firm representatives at the associate and managing partner levels, as well as student and law school representatives. 
- Similar initiatives have also been established by the law schools in the state of Ohio (which have established the Racial Fairness Project); ${ }^{71}$ Archer and Grenier; ${ }^{72}$ Dewey \& Le Boeuf LLP; ${ }^{73}$ Faegre \& Benson LLP. ${ }^{74}$ and Canadian law schools at the University of Saskatchewan ${ }^{75}$ and Dalhousie University. ${ }^{76}$

- Further, in co-operation with law schools across the U.S., the American Bar Association (ABA) has established the Legal Opportunity Scholarship Fund to support students who would otherwise not be able to afford a legal education. ${ }^{77}$

- Dewey \& LeBeouf LLP participate annually in the Black Law Students Association annual student recruiting conferences as well as Legal Outreach, a program to encourage inner-city high school students to consider law as a career. This firm also participated in the Brooklyn Legal Services Internship Program as well as with Sponsors for Educational Opportunity's corporate law program. ${ }^{78}$

- $\quad$ Faegre \& Benson L.LP works with the Minnesota Minority Recruitment Conference and Southeastern Minority Job Fair which hosts job fairs aimed at attracting lawyers of colour. ${ }^{79}$

- Parker Poe Adams \& Bernstein LLP recruits first-year "minority" associates each summer through the North Carolina Bar Association Minority Recruitment Program or through direct contact with potential students. ${ }^{80}$

- $\quad$ Perkins Coie works with a number of organizations that are actively addressing development, hiring, and retention of lawyers from diverse backgrounds, for example the Washington State Minority and Justice Commission; Ninth Circuit

See Ohio Commission on Racial Fairness, The Report of the Ohio Commission on Racial Fairness (1999), online: The Supreme Court of Ohio <http://www.sconet.state.oh.us.publications/fairness/ fairness.pdf>.

See "Commitment to Diversity," online: Archer \& Greiner <http://www.archerlaw.com/firm.php? category $=$ Careers\&headline $=$ Commitment + to + Diversity $>$. See "Diversity - Recruiting," online: Dewey \& LeBoeuf $<$ http://www.deweyleboeuf.com/firm/diversity/ recruitment.asp $>$. See "Recruiting - Our Commitment to Diversity," online: Faegre \& Benson LLP $<\mathrm{http}: / / w w w . f a e g r e$. com/recruiting/diversity.asp $>$.

Native Law Centre, online: University of Saskatchewan $<$ http://www.usask.ca/calendar/lawcollege/ programs/nativelaw/>. Indigenous Blacks \& Mi'kmaq Initiative, online: IB\&M Initiative $<$ http://ibandm.law.dal.ca $>$. See "ABA Legal Opportunity Scholarship Fund," online: American Bar Association (ABA) $<$ http://www.abanet.org/fje/lsmp.html>. Some of the law schools that have committed to participate include: University of Chicago School of Law; Drake University Law School; Duke University School of Law; Fordham University School of Law; Hofstra University Law School; Marquette University Law School; University of New Mexico School of Law; Northwestern University School of Law; Oklahoma City University School of Law; Rutgers University School of Law - Camden; Seton Hall University School of Law; Yale Law School; and Benjamin Cardozo School of Law, Yeshiva University. Supra note 73. Supra note 74. See online: Parker Poe <http://www.parkerpoe.com/>. 
Task Force on Race, Religion and Ethnic Fairness; Seattle-King County Bar Association/Diversity Coalition and Diversity Merit Program. ${ }^{81}$

- Several law firms and law schools attend job and university fairs established specifically for "minority's students," ${ }^{82}$ and several law schools engage their alumni in outreach initiatives, including the University of Georgia, the University of Texas, the University of Wisconsin, Florida A\&M University, and Florida International University. ${ }^{83}$

In referencing these promising practices, it is instructive to acknowledge their targeted focus and the degree of co-operation between law firms, law schools, bar associations, high schools, and university and community organizations for subordinate racialized groups. These partnerships allow for diverse interests to work together for a common goal, one that is clear and produces definable numerical results within designated timelines. If we were to truly "unbleach" the legal profession, these are the kinds of programs that would be useful to put into place in Alberta - programs that specifically name their purpose, take the leadership to construct essential partnerships, and then challenge and change their institutional structures to ensure the success of Aboriginal peoples and subordinate racialized groups in the study and practice of law.

\section{B. Regulators and Legal Associations}

Research and guidance on how to proceed with increasing the diversity of law schools and law firms is essential. In this regard, such research has been conducted by several associations. Some of these studies include:

- The Dallas Diversity Task Force that surveyed the 20 largest law firms in Dallas Texas in 2006. This was a collaborative project involving the Dallas Asian American Bar Association, the Dallas Hispanic Bar Association, and the J.L. Turner Legal Association. In addition to identifying the diverse makeup of these 20 firms, it discusses strategies to recruit, retain, and promote lawyers from diverse communities; ${ }^{84}$

See "Diversity," online: Perkins Coie <http://www.perkinscoie.com/diversity/Diversity.aspx>.

For example, such activities are conducted by Archer \& Grenier, the University of Georgia Law School, Faegre \& Benson LLP, the University of Wisconsin Law School, the University of Texas Law School, Perkins Coie LLP, and others. In particular, Parker Poe Adams \& Bernstein LLP recruit directly from the historically African American North Carolina Central University Law School.

Canadian Bar Association, The CBA Equity and Diversity Guide and Resource Manual for Successful Law Firms and Legal Organizations (Ottawa: Canadian Bar Association, 2007) at 18 [CBA, Equality and Diversity Guide]. This document also provided the framework from which the above examples were derived.

${ }_{84}$ See Dallas Diversity Task Force, Law Firm Diversity Report: Dallas - 2007, online: Dallas Diversity Task Force $<$ http://www.diversitytaskforce.com>. 
- The Law Society of England and Wales has produced a Diversity Access Scheme: Diversity in Action -- A Guide for Solicitors, ${ }^{85}$ and the Equality \& Diversity Strategy; ${ }^{86}$

- The ABA has produced the American Bar Association Resource Guide: Programs to Advance Racial and Ethnic Diversity in the Legal Profession; ${ }^{87}$

- The Columbus Bar Association has produced the Final Report and Action Plan of the Columbus Managing Partner's Diversity Initiative - 2000-01; ${ }^{88}$

- The National Association for Law Placement produced Diversity Best Practices Guide:

In an effort to further advance the important diversity enhancement efforts of the legal community ... this Guide [is designed] to assist legal employers in moving from abstract discussions about diversity to practical implementation of diversity strategies and initiatives. This Guide is a compilation of best diversity practices derived from industry research and interviews of law firm professionals across the country. Albeit comprehensive, this Guide does not purport to be exhaustive of all diversity best practices. Rather, it strives to serve as a resource for legal employers aiming to craft tailor-made diversity plans that best fit their organizational culture and goals.

...[The] Guide is organized into four topics:

- Leadership;

- Retention, Culture, and Inclusion;

- Professional Development; and

- Recruitment. $^{89}$

In Canada, there are some examples we can look toward. For example:

The LSUC has a mentoring program and a high school outreach program; law societies in British Columbia, Saskatchewan, Manitoba, Alberta, Nova Scotia, and Ontario have some form of discrimination harassment counsel to enable individuals to seek advice and support if they perceive they have been discriminated against by a lawyer; 90

The Law Society, Diversity Access Scheme: Diversity In Action - A Guide for Solicitors, online: The Law Society $<$ http://www.lawsociety.org.uk/becomingasolicitor/careerinlaw/equityanddiversity.law>. The Law Society of Scotland, Equality and Diversity Strategy: An integrated Equality \& Diversity Strategy for 2005 to 2008 (Rev. 1), online: the Law Society of Scotland <http://www.lawscot.org.uk/ uploads/Equality_Diversity/Equality\%20Strategy\%20(Rev\%202).pdf>.

(July 2000), online: ABA <http://www.abanet.org/leadership/recmenu.html>.

Online: Columbus Bar Association <http://www.cbalaw.org/projects/diversity/index.php>.

National Association of Legal Professional (NALP), Diversity Best Practices Guide (3 March 2006), online: NALP $<$ http://www.nalp.org/assets/221_diversitybestpracticegui.pdf $>$ at 2.

CBA, Equality and Diversity Guide, supra note 83 at 20. 
- Law societies and the CBA have established codes of conduct on discrimination and harassment to address individual acts and systemic issues. As well, these organizations have developed numerous model policies to guide the profession. ${ }^{91}$

- $\quad$ Pre-law programs have been established by the University of Saskatchewan through its Native Law Centre of Canada and through Dalhousie University's Faculty of Law's "Indigenous Black \& Mi'kmaq Initiative."

In addition to these programs, in August 2007, the CBA released The CBA Equity and Diversity Guide and Resource Manual for Successful Law Firms and Legal Organizations. ${ }^{93}$ This document also contains a training video series entitled, "It's About Respect" on harassment and discrimination in law firms. As Equity Advisor to the CBA, I was instrumental in accessing the funding for these materials, guiding the development of the video series, convening consultations across the country on the Guide and the Resource Manual, and leading the drafting of these documents. ${ }^{94}$

The CBA materials have been put together to assist and enhance efforts to promote equity and diversity in law firms and other organizations in the legal profession (law schools, government departments, regulatory bodies and voluntary associations). "The[ir] fundamental premise is that equity and diversity are core business requirements, and must be evident in all aspects of the workplace. ${ }^{95}$

Distinct from the other materials noted above, the CBA's publications promote the importance of a systemic approach that addresses four key areas requiring organizational action. These are: leadership; recruitment; professional development, retention, and advancement; and education and training. In each area, numerous strategies are identified and examples given of policies or practices developed and being implemented in law firms and other organizations.

\section{CONCLuSION}

While there has been some increase in the racial diversity of law school students and members of the legal profession, this diversity needs to be increased dramatically in order to develop a critical mass of Aboriginal lawyers and lawyers from subordinate racialized groups so that the legal profession will be at the same level of other professions and begin to reflect the makeup of the population.

To achieve this goal, law schools and law firms must demonstrate clear and unequivocal leadership that is measurable and that has specific timelines. The importance of this matter is underscored when considering the social significance of attaining a legal education, a point which is well articulated in the University of Windsor study on law school admissions

For a summary of many of these initiatives, see $i b i d$.

See "Programs and Projects," online: Native Law Centre of Canada <http://www.usask.ca/nativelaw/ programs/>; online: IB \& M Initiative $<$ http://ibandm.law.dal.ca/index.htm $>$.

Supra note 83.

Consultations were held in Vancouver, Winnipeg, Halifax, Montreal, Ottawa, Toronto, and Regina.

Supra note 83 at 5. 


\section{criteria:}

By necessity, the nature, quality, and effectiveness of the legal system is greatly dependent on the types of individuals who receive a formal legal education. As lawyers, judges, educators, administrators, and legislators, legally trained persons control or materially affect the majority of decision-making and lawenactment processes in society. Law school graduates continue to develop careers in many non-traditional occupations requiring legal expertise; this broadens the profession's sphere of influence. Thus, the legal system, intended for the benefit of all members of society, reflects in some measure the cultural, social, and economic views of the legally trained. To the extent that the legally trained influence the organs of government, access to formal legal education can also be viewed as an important determinant of the political, social, and economic reality. Yet, legal education has traditionally been accessible only to majority social groups in Canada. Therefore, minority perspectives concerning our societal choices may have had only limited influence. ${ }^{96}$

This is what we have to change. 